УДК 656.073:006.83

\title{
МЕТОДИЧНІ ПІДХОДИ ДО ВИЗНАЧЕННЯ ЯКОСТІ ТРАНСПОРТНОГО ОБСЛУГОВУВАННЯ ВАНТАЖОВІДПРАВНИКІВ
}

\author{
Семенцова О.В., к.е.н, доцент (УкрДУЗТ)
}

\begin{abstract}
Проведено дослідження підходів щзодо визначення якості транспортного обслуговування вантажсовідправників. Зроблено висновки про доиільності використання узагальнюючого показника якості, який враховував би сукупність складових простих показників якості (вчасність доставки, збереження вантажу, можливість перевезення «від дверей до дверей», задоволення попиту вантажовідправників на перевезення, вплив на оточуюче середовище). Наведено методичні підходи до визначення якості транспортного обслуговування вантажовласників.
\end{abstract}

Ключові слова: залізничний транспорт, вантажні перевезення, якість транспортного обслуговування вантажжовідравників

\section{МЕТОДИЧЕСКИЕ ПОДХОДЫ К ОПРЕДЕЛЕНИЮ КАЧЕСТВА ТРАНСПОРТНОГО ОБСЛУЖИВАНИЯ ГРУЗООТПРАВИТЕЛЕЙ}

\author{
Семенцова Е.В., к.э.н., доцент (УкрГУЖТ)
}

Проведено исследование подходов к определению качества транспортного обслуживания грузоотправителей. Сделаны выводы о иелесообразности использования обобщающего показателя качества, который учитывал бы совокупность составляющих простых показателей качества (своевременность доставки, сохранность груза, возможность перевозки «от двери до двери», удовлетворение спроса грузоотправителей на перевозку, влияние на окружающую среду). Приведень методические подходы к определению качества транспортного обслуживания грузовладельцев.

Ключевые слова: железнодорожный транспорт, грузовые перевозки, качество транспортного обслуживания грузоотправителей

\section{APPROACHES TO DETERMINING THE QUALITY OF TRANSPORT SERVICE SHIPPERS}

Sementsova O.V., ph.d., assoc., associate professor (Ukrainian state university of railway transport)

Materials article contains research results of approaches to determine the quality of transport service shippers. The conclusions about the appropriateness of using summary measure of quality that takes into account the totality of the components of simple indicators of quality of service shippers (timely delivery of cargo, cargo safety in quantitative and qualitative terms, the complexity of a single operator delivery cargo traffic, full satisfaction of the demand of shippers for the transportation, environmental impact). The methodical approaches to determining the quality of transport services cargo. The proposed methodological approach is comprehensive and is based on the basis of the totality of simple indicators of quality of transport service shippers into a single index, based on their ranking. For the ranking of simple indicators of quality appropriate to use the method of expert evaluations. This approach creates the conditions for a better reflection of the quality of service the industry, and obtained by the set of methodological approaches results of calculations of the quality of transport services will create conditions for the effective monitoring and improving the level of service and monitoring the competitiveness of industry in this market segment.

Keywords: rail, cargo, quality of transport service shippers

Постановка проблеми та іiї зв'язки 3 науковими та практичними завданнями. На ринку сучасних транспортних послуг спостерігається досить активний розвиток, що обумовлює підвищення конкуренції між різними видами транспорту та транспортними організаціями. У таких умовах актуальною $\epsilon$ проблема підвищення конкурентоспроможності транспортного підприємства за допомогою поліпшення якості обслуговування та надання споживачам транспортних послуг. Якість транспортних послуг - важлива складова у закріпленні конкурентоспроможності підприємства на ринку. Адже конкурентоспроможність підприємства залежить від якості його послуг, тобто від того, у якій мірі продукція підприємства задовольняє вимоги споживача.

В умовах розвитку конкуренції, зокрема i

(C) Семенцова O.B.

Вісник економіки транспорту і промисловості № 50, 2015 
міжгалузевої, все більшої актуальності набуває необхідність зацікавлення споживачів послугами залізничного транспорту. Залізничний транспорт має досить вагомі переваги відносно якості надання послуг 3 перевезень. Завдяки цьому залізничний транспорт займає високу питому вагу в сегменті перевезень вантажу.

Діяльність по управлінню якістю і їі підвищенню завжди здійснювалася на залізничному транспорті перш за все в області безпеки руху. Але в приватному секторі ринку транспортних послуг ведеться активна робота по системному управлінню якістю послуг, що надаються пасажирам. Що ж до залізничного транспорту, ця проблема недостатньо розв'язана, що і обумовлює актуальність обраної теми.

Аналіз останніх досліджень і публікацій, на які спирасться автор 3 посилання на джерела. Задоволення потреб населення в перевезеннях - $є$ основним завданням транспорту. Огляд публікацій $з$ питань якості транспортного обслуговування показав, що 3 ці аспекти висвітлено у великій кількості наукових та практичних робіт. Здійснювати управління якістю перевезень неможливо, якщо не визначитися, що розуміти під якістю транспортної продукції, якими показниками ii оцінювати. Аспектам вивчення поняття якості залізничних перевезень та показників, що іiі визначають, займалися такі вітчизняні та закордонні фахівці та науковці, як Балалаєв С. О. [1], Галабурда В. Г. [2], Дайлідко О. О. [3], Іловайський Н. Д. [4], Макаренко М. В. [5], Терешина Н. П. [6] та інші.

Виділення невирішених частин загальної проблеми, котрій присвячується стаття. Не зважаючи на різноманітність робіт, присвячений вивченню аспектів визначення якості залізничних перевезень лишається відкритим питання що визначення узагальнюючого показника якості транспортного обслуговування вантажовласників, що і обумовило мету статті.

Виклад основного матеріалу дослідження 3 обгрунтуванням отриманих наукових результатів. Узагальнюючий показник якості транспортного обслуговування вантажовідправників уособлює в собі наступну сукупність простих показників, чільне місце серед яких посідають: вчасність доставки вантажу, збереження вантажу в кількісній та якісній формі, комплексність обслуговування вантажовласників єдиним оператором перевезень (можливість здійснення перевезення «від дверей до дверей»), задоволення попиту вантажовідправників на перевезення, вплив на довколишнє середовище перевезень.

Отже, видається, що узагальнюючий показник якості транспортного обслуговування вантажовідправників ( $K_{\text {заг }}$ ) доцільно визначати як сукупність простих показників якості, скорегованих на вагу їх важливості для вантажовідправників за формулою

$$
K_{\text {заг }}=\sum_{i=1}^{n} K_{i} \cdot \alpha_{i},
$$

де $K_{i}$ - рівень конкретного $\cdot i$-го простого показника якості транспортного обслуговування ( $i=1, \ldots \boldsymbol{n}$, де $\boldsymbol{n}$ - кількість простих показників якості транспортного обслуговування, що враховуються в узагальнюючому);

$$
\alpha_{i} \text { - питома вага важливості } \cdot i \text {-го }
$$

простого показника якості транспортного обслуговування.

Коефіцієнт вчасності доставки вантажу

( $K_{\text {дост }}$ ) визначається за формулою

$$
K_{\text {дост }}=\frac{\sum Q^{\text {вчас }}}{\sum Q^{\text {заг }}}
$$

де $\sum Q^{\text {вчас }}$ - фактичний обсяг перевезень

вантажу, що доставлено вантажоотримувачам 3 дотриманням встановлених нормативних термінів доставки, тис. тонн;

$\sum Q^{\text {заг }}$ - загальний обсяг перевезень вантажу, тис. тонн.

Коефіцієнт кількісного збереження вантажу $K^{\text {кіл }}$

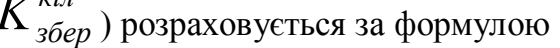

$$
\begin{aligned}
& K_{\text {кбер }}^{\text {кіл }}=\left(1-\frac{\sum Q^{\text {втрач }}}{\sum Q^{\text {заг }}}\right), \\
& \text { де } \sum Q^{\text {втрач }} \text { - фактичний обсяг }
\end{aligned}
$$

перевезень вантажу, що втрачено з вини залізниці, тис. тонн.

Коефіцієнт якісного збереження вантажу

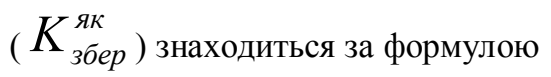




$$
K_{\text {збер }}^{\text {як }}=\left(1-\frac{\sum Q^{\text {зinc }}}{\sum Q^{\text {заг }}}\right),(4)
$$

де $\sum Q^{\text {sinc }}$ - фактичний обсяг перевезень

вантажу, що втрачено через псування 3 вини залізниці, тис. тонн.

Коефіцієнт комплексності обслуговування вантажовласників $\left(K_{\text {компл }}\right)$ обчислюється за формулою

$$
K_{\text {комил }}=\frac{\sum Q^{\text {коиил }} \cdot \alpha_{\text {комил }}}{\sum Q^{\text {заг }}},
$$

де $\sum Q^{\text {компл }}$ - обсяг комплексних

перевезень вантажів «від дверей складу до дверей вантажоотримувачів» під'їзною залізничною колією або автотранспортом залізниць, тис. тонн;

$$
\alpha^{\text {компл }} \text { - коефіцієнт, що враховує рівень }
$$

комплексності доставки вантажу єдиним оператором перевезень.

Коефіцієнт задоволеності попиту вантажовідправників $\left(K_{3 n}\right)$ встановлюється за формулою

$$
\begin{aligned}
& K_{\text {зи }}=1-\frac{\sum Q^{\text {невідпр }}}{\sum Q^{\text {заг }}}, \\
& \text { де } \sum Q^{\text {невідрр }} \text { - обсяг перевезень } 3
\end{aligned}
$$

числа заявлених до перевезення 3 вини залізниці, тис. тонн.

$$
\text { Коефіцієнт впливу на довколишнє }
$$
середовище ( $K_{\text {екол }}$ ) знаходиться за формулою

$$
\begin{gathered}
K_{\text {екол }}=\frac{Y^{\text {норм }}}{Y^{\text {факт }}, \text { за умови, якщо }} \\
Y^{\text {норм }}<Y^{\text {факт }} \\
\text { де } Y^{\text {норм }} \text { - нормативна величина }
\end{gathered}
$$

шкідливого впливу на оточуюче середовище від роботи залізничного транспорту 3 перевезень вантажу (визначається технічними нормами та технологічними інструкціями);

$Y^{\text {норм }}$ - фактична величина шкідливого впливу на оточуюче середовище від роботи залізничного транспорту з перевезень вантажу.

Необхідно зауважити, що за умови коли $Y^{\text {норм }} \geq Y^{\text {факт }}, \quad$ коефіцієнт впливу на довколишнє середовище дорівнюе одиниці ( $\left.K_{\text {екол }}=1\right)$.

Оцінку питомої ваги важливості $i$-го простого показника якості транспортного обслуговування доцільно проводити на основі ранжування його вагомості серед усієї сукупності показників, що $\epsilon$ можливим отримати за допомогою методу експертних оцінок.

Для визначення важливості $i$-го простого показника якості транспортного обслуговування

$\left(\alpha_{i}\right)$ можна скористатися формулою

$$
\alpha_{i}=\frac{B_{i}}{\sum_{i=1}^{n} B_{i}},
$$

де $B_{i}$ - сумарне значення оцінок, що виставлені експертами відповідному $i$-му простому показника якості транспортного обслуговування;

$$
\sum_{i=1}^{n} B \text { - сумарне значення усіх оцінок, що }
$$

встановлено усіма експертами за всіма простими показниками якості транспортного обслуговування.

Висновки даного дослідження i перспективи подалыших робіт $\mathbf{y}$ цьому напрямку. Запропоновані підходи до визначення показника якості транспортного обслуговування вантажовідправників залізничним транспортом України, створює умови для удосконалення аналізу якості надання послуг галузі, а отримані 3 допомогою викладених методичних підходів результати розрахунків якості транспортного обслуговування створять умови для ефективного контролю та удосконалення рівня надання послуги й моніторингу конкурентоспроможність галузі в даному сегменті ринку. В подальшому даний підхід може бути розширений шляхом врахування більшого кола чинників, що мають вагу для окремих операторів перевезень та вантажовідправників.

\section{СПИСОК ЛІТЕРАТУРИ}

1 Балалаев, С. А. Императивы качества в сфере железнодорожного транспорта [Текст] /

Вісник економіки транспорту і промисловості № 50, 2015 
С. А. Балалаев, Р. Г. Леонтьев // Транспорт : наука, техника, управление. - 2006. - № 1. - С. $14-18$.

2 Галабурда, В.Г. Методология корпоративного управления качеством транспортного обслуживания пользователей на железнодорожном транспорте [Текст] / В. Г. Галабурда // Железнодорожный транспорт (Серия «Маркетинг и коммерческая деятельность»). ЭИ/ЦНИИТЭИ. - 2004. - Вып. 2. - С. 1-22. -

3 Дайлидко, А. А. Стандартизация, метрология и сертификация на железнодорожном транспорте [Текст] : учеб. изд. / А. А. Дайлидко, Ю. А. Юрченко. - М. : Желдориздат, 2008. - 261 с.

4 Иловайский, Н. Д. Сервис на транспорте (железнодорожном) [Текст] / Н. Д. Иловайский, А. Н. Кисилев : Учебник для вузов. - М. : Маршрут, 2003. -59 c.

5 Макаренко, М. В. Основи управління економічними процесами на залізничному транспорті України. [Текст] / М. В. Макаренко К. : КУЕТТ, 2003. - 478 c.

6 Экономика железнодорожного транспорта [Текст] : Учеб. для вузов ж.-д. транспорта / Н.П. Терёшина, В.Г. Галабурда, М.Ф. Трихунков и др.; Под ред. Н.П. Терёшиной, Б.М. Лапидуса, М.Ф. Трихункова. - М.: УМЦ ЖДТ, 2006. - 276 с.

Рецензент д.е.н., професор УкрДУЗТ Дейнека О.Г. Експерт редакційної колегії к.е.н., дочент УкрДУЗТ Боровик Ю.Т.

УДК 658.5.009.12:338.436

\title{
АКТУАЛЬНІСТЬ ФОРМУВАННЯ ТРАНСПОРТНО-ЛОГІСТИЧНИХ СИСТЕМ В УМОВАХ ЄВРОІНТЕГРАЦЇ̈
}

\author{
Устенко М. О., к.е.н., доцент (УкрДУЗТ)
}

У статті досліджено основні проблеми формування та розвитку транспортно-логістичних систем в умовах європейської інтеграції, обтрунтовано актуальність розвитку та необхіність впровадження транспортно-логістичних систем, визначено вплив логістики як одного з ефективних інструментів планування організації та управління на транспортний комплекс Украӥни, визначено структуру транспортно-логістичної системи Украӥни, проаналізовано досвід розвинутих краӥн у використання логістичних систем.

Ключові слова: логістика, транспортно-логістична система, логістичний підхід, інтеграція, логістизация, підприємство, транспорт, міжннародні транспортні коридори

\section{АКТУАЛЬНОСТЬ ФОРМИРОВАНИЯ ТРАНСПОРТНО-ЛОГИСТИЧЕСКИХ СИСТЕМ В УСЛОВИЯХ ЕВРОИНТЕГРАЦИИ}

\author{
Устенко М. А., к.э.н., доцент (УкрГУЖТ)
}

В статье исследованы основные проблемь формирования и развития транспортнологистических систем в условиях европейской интеграции, обоснована актуальность развития и необходимость внедрения транспортно-логистических систем, определено влияние логистики как одного из эффективных инструментов планирования организации и управления на транспортный комплекс Украины, определена структура транспортно-логистической системь Украины, проанализирован опыт развитых стран в использование логистических систем.

Ключевые слова: логистика, транспортно-логистическая система, логистический подход, интеграция, логистизация, предприятие, транспорт, международные транспортные коридоры

\section{ACTUALITY OF TRANSPORT AND LOGISTIC SYSTEMS FORMATION IN EUROINTEGRATION}

\section{Ustenko M.O., Candidate of Economic Sciences (USU of RT)}

In the article the basic problems of forming and development of transport and logistics systems in terms of European integration, the urgency of the need to implement transportation and logistics systems, the influence of logistics as one of the effective tools for planning the organization and management of transport complex in

(C) Устенко М.O.

Вісник економіки транспорту і промисловості № 50, 2015 